\title{
Rewards
}

\section{How do employees want to be shown appreciation? Results from 100,000 employees}

\author{
Paul White
}

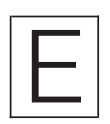

mployee recognition and communicating appreciation to team members have been shown to be important factors relevant to employee engagement and job satisfaction (Mann and Dvorak, 2016). However, in spite of the proliferation of employee recognition programs, to the point that 85 per cent of all organizations have some recognition activities (Daniel and Metcalf, 2005), the levels of employee engagement have not changed significantly in the past several years (Adkins, 2016).

In fact, it has become increasingly clear that many aspects of traditional employee recognition programs - their generic nature, primarily rewarding years of service or "above and beyond performance", and having recipients receive accolades in front of large groups - actually create negative responses from many employees (White, 2016b).

A core concept foundational to demonstrating authentic appreciation is that not everyone wants to be shown appreciation in the same ways. When appreciation is shown in the ways most meaningful to the recipient, many positive results occur: improvement in relationships with colleagues and supervisors, decrease in absenteeism, increase in employee engagement rises, as do customer satisfaction ratings (White, 2017).

The Motivating by Appreciation (MBA) Inventory (White, 2016a) is an online assessment based on the concepts from the book The 5 Languages of Appreciation in the Workplace (Chapman and White, 2011). The five languages of appreciation are:

1. Words of affirmation: Verbal praise can be communicated orally or in writing. Common examples include a word of thanks from a colleague for a specific action or an email with a compliment from one's supervisor.

2. Quality time: Some people feel valued when others spend time with them. This can be shown either through individual time with their supervisor or being able to hang out with their co-workers.

3. Acts of service: For some, they need appreciation shown through actions. Helping a colleague when they are behind on a time-sensitive project or just working together to complete a task are two common examples.
Paul White is President of Appreciation at Work, Wichita, Kansas, USA. 
4. Tangible gifts: In the context of workplace appreciation, gifts are not related to compensation (raises, bonuses), but they are small items that demonstrate acknowledgement of one's teammates - their favorite cup of coffee, a magazine about one of their hobbies or a special snack they would enjoy.

5. Physical touch: Appropriate physical touch in the workplace is a sensitive issue, but the focus really is on ways people use touch in spontaneous celebration - a high five, a fist bump or a congratulatory handshake.

The MBA Inventory assesses an individual's primary language of appreciation, secondary language of appreciation and their least-valued appreciation language and then provides an individualized report of the results. (Note: while all five appreciation languages are addressed in The 5 Languages of Appreciation in the Workplace and the Appreciation at Work training materials, the language of physical touch is not assessed in the inventory to avoid negative reactions by individuals who have experienced sexual harassment in the workplace). Over 100,000 employees have taken the MBA Inventory, and the data from the responses of those who have taken the inventory were analyzed.

\section{Words of affirmation are most desired}

Employees overwhelmingly choose receiving words of affirmation as the primary way they like to be shown appreciation in the workplace. Almost half of all employees (47 per cent) cite receiving verbal praise as their primary language of appreciation. Note that verbal compliments can be delivered in various ways: orally, in writing, privately in a one-on-one conversation, in front of one's team members or in front of a large group. The inventory allows each respondent to choose the specific actions they prefer, so the appreciation can be customized for each person.

Why do words of affirmation seem to be so desired by employees? We do not know definitively, but two primary reasons appear relevant. First, the high use of words seems to be partially related to enculturation - words have been the way encouragement has been communicated in the workplace historically. Thus, it appears using words is partially a learned behavior. Second, showing appreciation through words typically is fairly easy to do, and it takes less effort than some of the other appreciation languages.

\section{Tangible gifts are the least desired}

Again, the evidence is clear. When asked to compare the various languages of appreciation in terms of importance to them, employees overwhelmingly did not choose tangible rewards as the primary way they wanted to be shown appreciation. In fact, only about 6 per cent of employees identify tangible gifts as their primary language of appreciation. To look at the issue from the opposite perspective, employees choose tangible gifts as the least-valued way to be shown appreciation 67 per cent of the time.

But interpreting the data correctly is important. Employees are not saying they do not want tangible rewards (gift cards, going out to eat, earning a trip) for doing good work. But what the data show is that when choosing comparatively between words of affirmation, quality time or an act of service - receiving a gift is far less meaningful than appreciation communicated through these actions. For example, employees often comment, "If I receive some gift but I never hear any praise, no one stops to see how I'm doing, or I never get any help the gift feels superficial".

\section{No gender differences}

There are essentially no differences across genders in the frequency of how often men and women choose the various languages of appreciation, almost to an amazing degree. Whether the question is regarding primary, secondary or least-valued languages of appreciation, the frequency rate for women and men is incredibly similar. In fact, the difference in the frequency between how often women and men choose each primary of language of appreciation is miniscule (Table I).

It should be noted that there are gender differences in how individuals want to be shown appreciation, but these are at the level of specific actions within the appreciation language, rather than across languages. For example, many women who value quality time enjoy getting together with one or two friends to have a meal and chat, while men typically are more likely to choose watching

\begin{tabular}{|c|c|c|c|}
\hline Table I & $\begin{array}{l}\text { Apl } \\
\text { dis } \\
\text { MB } \\
\text { lan } \\
(N\end{array}$ & $\begin{array}{l}\text { reciation la } \\
\text { ribution res } \\
\text { A inventory } \\
\text { Juage of ap } \\
=104,165)\end{array}$ & $\begin{array}{l}\text { anguage } \\
\text { ults using } \\
\text { 's primary } \\
\text { opreciation }\end{array}$ \\
\hline \multicolumn{2}{|c|}{$\begin{array}{l}\text { Appreciation } \\
\text { language }\end{array}$} & Males (\%) & Females (\%) \\
\hline \multicolumn{2}{|l|}{ Gifts } & 5.6 & 5.5 \\
\hline \multicolumn{2}{|l|}{ Services } & 26.1 & 20.8 \\
\hline \multicolumn{2}{|l|}{ Time } & 23.2 & 25.5 \\
\hline \multicolumn{2}{|l|}{ Words } & 45.1 & 48.2 \\
\hline
\end{tabular}


sports or doing an activity

together.

\section{Quality time is an important secondary language}

While acts of service (22.5 per cent) and quality time (24.7 per cent) are chosen frequently at a similar rate by employees as their primary language, some additional data shed further light on these two appreciation languages.

First, when looking at what language individuals choose as their secondary appreciation language, quality time (36 per cent) is preferred over acts of service (26 per cent). Additionally, quality time is the least-valued language for 7.4 per cent of the population, but acts of service is more frequently chosen as the least-valued way to be shown appreciation, 18.4 per cent of the time. Thus, overall, quality time appears to be people's second most desired way to be shown appreciation.

\section{Summary}

Communicating appreciation to employees in ways that they prefer to receive it is one of the core components to help them feel truly valued for their contributions.

Discovering the specific language of appreciation (and actions within their primary appreciation language) has been shown to be effective in increasing employees' sense of feeling appreciated (White, 2016b, 2017).

Data from over 100,000 respondents to the MBA Inventory indicate that words of affirmation are employees' first choice for being shown appreciation, by 47 per cent of respondents. Quality time (25 per cent) and acts of service (22 per cent) are desired by large numbers of employees as well.

But when compared to the other languages of appreciation, receiving rewards or tangible gifts are the least chosen manner in which employees want to be shown appreciation - by less than 6 per cent of all employees. This is clearly an important message for human resource $(\mathrm{HR})$ professionals to hear - tangible gifts are not the primary way in which over 90 per cent of employees want to be shown appreciation. Thus, if an organization is trying to use rewards to communicate appreciation to their employees, they are not only missing the mark, but probably wasting a lot of money!

While knowing the trends across the workforce can be helpful in understanding your employees' results on the MBA Inventory, the most important information is to know how your individual team members desire to be appreciated and communicate in the language and actions most important to them. The vast majority of employees would prefer some individual time and attention, help on tasks (especially on time-sensitive projects) and hear specifically what others appreciate about them.

\section{References}

Adkins, A. (2016), "Employee engagement in US stagnant in 2015", Gallup, January, available at: www. gallup.com/poll/188144/employeeengagement-stagnant-2015.aspx

Chapman, G. and White, P. (2011), The 5 Languages of Appreciation in the Workplace, Northfield Press, Chicago, IL.

Daniel, T. and Metcalf, G. (2005), "The fundamentals of employee recognition", available at: www.researchgate.net/ publication/228494649_The_ fundamentals_of_employee_recognition

Mann, A. and Dvorak (2016), "Employee recognition: low cost, high impact", available at: www.gallup.com businessjournal/193238/employeerecognition-low-cost-highimpact.aspx

White, P. (2016a), "Appreciation at work training and the motivating by appreciation inventory: development and validity", Strategic HR Review, Vol. 15 No. 1, pp. 20-24, doi: 10.1108/ SHR-11-2015-0090.

White, P. (2016b), "Why most employee recognition programs don't work", available at: www.govloop.com/ community/blog/employee-recognitionprograms-dont-work

White, P. (2017), The Vibrant Workplace: Overcoming the Obstacles to Building a Culture of Appreciation, Northfield Press, Chicago, IL.

\section{Corresponding author}

Paul White can be contacted at: paul@drpaulwhite.com 